UDC: $340.001 .73: 378.1$

DOI: https://doi.org/10.24195/2414-4665-2017-2-15

Kateryna Nekit,

PhD (law), associate professor, Department of Civil Law, National University "Odessa Law Academy", 23, Fontanska Doroha Str., Odessa, Ukraine

\title{
MODERN CHALLENGES OF REFORMING LEGAL EDUCATION IN UKRAINE
}

The article deals with the analysis of the current stage of legal education reforming in Ukraine. There is a discrepancy between the tasks of the reforms, set by the Bologna Process, and its objectives. In particular, there is improper understanding of the essence of student-centered concept, which results in its incorrect implementation into the educational process. Studentcentered teaching involves active participation of a student in the educational process, particularly in the process of educational content determination and assessment. Special attention in the paper is paid to the disadvantages of the current system of students' academic achievements assessment. The project of the Concept of perfection of legal (juridical) education for specialized training of lawyers according to the European standards of higher education and the legal profession has been analyzed in the study. Some recommendations about the improvement of the reforms in the field of legal education have been suggested. In particular, there is the need for increasing students' personal responsibility, proper planning of students' independent work, development of adequate methods of students' knowledge assessment, increasing the role of written essays for the formation of professional competencies of students majoring in Law.

Keywords: legal education, reforming, concept of improvement of legal education, student-centered teaching, assessment.

\section{Introduction}

Ukraine is a state party of the Bologna process, so it is important to find out its ultimate goal and perform the necessary tasks on the way to its implementation. It is known that the main objective of the Bologna process is the creation of a common European education area. The main aim of creating a common European education area is providing the possibility of free movement of students and workers within EU countries. Providing this capability can be achieved only by the implementation of common standards and criteria for education and assessment of students. They, in turn, are provided with the development of credit transfer system, in which a certain number of credits is assigned in each discipline that allows students to receive credits for the studied subjects and not to retake exams in case of transferring to another university. Academic credits determine the amount of academic load which a student must perform in order to study a particular discipline and get the appropriate competence. Moreover, credits are kept forever, and therefore they provide not only students' mobility, but also accumulation of new knowledge throughout life. Ultimately, the Bologna process has to assure self-development of an individual throughout life.

The reforms taking place in the framework of the Bologna process are focused on the above mentioned issue but unfortunately, the majority of teachers and students do not understand their main goal. This causes a need for special studies that are directed at finding solutions to the problems faced by Ukraine in terms of education reforms, including legal education.

Issues of reforming legal education have repeatedly become a subject of scientists' research studies. In particular V. Zhuravskii, V. Zaichuk, S. Kivalov, M. Kravchuk,
Yu. Oborotov, P. Rabinovich, A. Skakun, V. Sushchenko, V. Tatsii, Yu. Shemshuchenko and others dedicated their works to this problem. Recently, however, the debates around the legal education reforming have gained momentum due to the offered project of the Concept of improving legal (juridical) education for professional training of lawyers in accordance with European standards of higher education and legal profession, the attitude to which is very controversial, that is why it also requires special attention.

The study aims to analyze the current state of legal education reforming, identify problems that arise in the course of taking reforms and find ways to meet the challenges faced by Ukraine in terms of reforming legal education.

\section{Discussion}

The problem of lack of understanding the essence and ultimate goal of the reforms that are taking place in the framework of the Bologna process concerns not only Ukraine. In 2008, large-scale demonstrations took place against the reforms in Spain since the Bologna system was time-consuming and made it impossible to study alongside employment (a great number of hours for selfstudy as a part of the Bologna education system should be used for working with additional sources, making tests, writing essays and not for having rest or working). Also in 2008 , in Croatia people protested against "superficial reforms". According to some experts, in most countries the educational system is changed formally (distinguishing Bachelor and Master degrees) but the mindset and attitude towards education remain unchanged [1]

Today in Europe many people believe that the Bologna system is worse in comparison with traditional education, which was aimed at the formation of a personality, not just an employee, that it educates people with- 
out the ability to think critically, etc. [1]. This opinion also has the right to exist, but each case needs consistency. So if a country chooses a certain path of development, it has to be consistent, especially when it concerns education.

Ukraine joined the Bologna Convention in 2005, but are real changes being felt now in education and law in particular? Real reforms started only last year but the implementation of the proposed measures into practice has a pronounced formal character. Furthermore, not all of the proposed measures which are planned and implemented in the process of reforming are effective enough. For example, free choice of subjects by students should be provided through polls, taking into account the opinion of each student. Moreover, the choice of specialization should be a conscious step of every student, while in real life there are cases of administrative decisions regarding the future specialization of young people [1].

Today not everyone understands the essence of the student-centered concept and features of its implementation. Student-centered education means the formation of programs and educational technologies not according to the teachers' and department's desire, but to requirements of future profession and students' opportunities [2, p. 136138]. Student-centered model is built at the intersection of three elements of the educational process: efficient educational environment (access to educational resources), interaction of teachers and students and involvement of students into the educational process, especially into monitoring processes of educational programs and improving assessment procedures. Regarding the interaction between teachers and students, their cooperation is based on the feedback principle, which involves not just final assessment when a student gets a mark which is a measure of his/her level of knowledge, but also teacher's comments about the mistakes and the ways of correcting and avoiding them [3, p. 163].

Participation in assessing the quality of teacher's work by students is provided by questionnaires about the wishes of course materials improvement, availability of teaching and quality assessment. Often in these cases the system of anonymous survey is used after completing a course. It takes into account the following specific features: teacher's readiness to carry on a dialogue and respond to the wishes of students; quality of learning material and its availability to understanding; structure and content of the course, its compliance with the requirements of business environment; technical and organizational conditions of the educational process; effectiveness of the assessment system [4, p. 96-97].

However, this approach involves the danger of unfair attitude of students towards a strict (in a good sense) teacher, because in the United States, for example, anonymous survey is combined with attending classes by specially designated persons whose primary function is to provide objective assessing of the level of teaching [5, p. 43-45].

Another aspect that needs improvement during the reforms is the requirements for students, in particular assessment of the results of their academic achievements. In most cases the countries participating in the Bologna convention just transfer the marks from the previous assessment system in ECTS credits using mathematical formulas. This happened, for example, in Lithuania, where national credits were just transferred according to mathematical principle that, in fact, does not reflect the load and academic achievements of students. In some countries (in Ukraine as well) national assessment system is used together with the ECTS credits which creates the discrepancy in the comparison of the two systems. ECTS credit allocation should be based on learning outcomes and load where the learning outcomes are developed for describing the learning activities, and load is considered to be the assessment of the total time students require to achieve them [6].

The Concept of improving legal (juridical) education for professional training of lawyers according to European standards of higher education and legal profession (hereinafter - the Concept) was designed to provide the reforming of legal education in the framework of the Bologna process. It is aimed at ensuring the Bologna Convention strategies on the implementation of university education quality assessment systems and attracting students and teachers to external evaluation of universities. The assessment of education quality is expected to be performed by accreditation agencies independent from national government and international organizations, and the assessment should be based not on the duration or content of education but on the knowledge and skills obtained by the graduates (p. 32 of the Concept). At the same time some standards of legal education are being set (p. 17 of the Concept). They are designed to provide compatibility and correspondence of levels which is necessary for mobility and recognition in case of moving to other countries or universities that are the cornerstones of the Bologna process [6].

Generally, the Concept has its strengths and weaknesses. Its main advantage is the implementation of a unified state examination in "Law", passing of which is a necessary condition. It aims to check the quality of education, verify compliance with the requirements, quality standards. In the future, the unified examination will make it possible to determine the ranking of the university - according to the success of graduates who pass it as it shows their academic achievements. On the other hand, this kind of assessment may result in artificial reduction of the number of people who would like to receive a degree in law. The implementation of external quality assessment only for legal education seems to be unfair, which obviously creates privileges to other students compared to those ones majoring in law.

The purposeful decrease of the number of future lawyers by the interdependence of the number of students who get their degree for free and those ones who pay for it is considered to be one more disadvantage of the Concept. Thus, according to the p. 29, the total amount of students majoring in Law should involve 50\% students who do not 
pay for their education and $50 \%$ of students studying on the contract base. Indeed, this approach not only violates the rights to freedom of choice of occupation (Art. 43 of the Constitution of Ukraine), but also ignores the interests of the business sector and civil society that can have even higher need for lawyers. It should be noted that public sector of economy is only $16.5 \%$ (according to the Ministry of Economic Development and Trade of Ukraine in the first half of 2016) of the total economy [7].

In addition, the proposed concept involves implementation of the comprehensive Master-degree course (instead of the current two-stage model "BachelorMaster"). This approach contradicts the popular conception of adaptation of Ukrainian legislation to European standards (in particular, there is a contradiction of Association Agreement between Ukraine and the EU on the issue of free movement of workers and students within the European area, on which the Bologna system is focused). Thus, the Bologna system provides the three-stage system of education which allocates Bachelor's, Master's and Doctor's degrees. At that Bachelor's degree is acquired after three years of studying and obtaining 180 ECTS credits and the Master's degree is assigned after two years of studying and obtaining 120 ECTS credits (in some cases, 4 years and 240 ECTS credits are necessary to receive Bachelor's degree and one more year and 60 ECTS credits - for Master's degree) [6].

Thus, the reforming of legal education in Ukraine in accordance with European standards requires not just the rejection of the allocation of Bachelor's and Master's degrees (which is required by the Bologna system for academic mobility), but coordination with the public authorities and approval of standards "Bachelor of Law" and "Master of Law" as it was proposed earlier [8].

\section{Conclusions}

Summing up, it should be stated that the real reforming of legal education in Ukraine has to be performed not by formalized approaches to the implementation of Credit Transfer System ideas, division into degrees and studentcentered approach, but by radical changes at the level of consciousness that have to be manifested in teachers' understanding of the need to achieve the high-quality results - training of workers who will be competitive at the labor market, as well as students' understanding that the time at the university should be spent for obtaining necessary competencies. The Bologna process should be

\section{REFERENCES}

1. Zubchenko, Ya. (2016). Bolonska systema poukrainski: lin ta manipuliatsiia [Bologna system in Ukraine: laziness and manipulation]. Retrieved from: http://osvita.ua/vnz/52421 [in Ukrainian].

2. Nosko, I. V. (2011). Studentotsentrirovannoe obrazovanie kak osnovopolagayushchiy printsip bolonskikh reform v vysshey shkole [Student-centered education as basic principle of Bologna reforms at universities]. Vektor nauki TGU. - Vector of science, 1(4), 136-138 [in Russian]. mainly focused on higher education liberalization, teaching students the principles of freedom and at the same time responsibility for their choice. The experience of western countries shows that the selection of disciplines by students according to their interests motivates them to study [9]. Unfortunately, there is a little bit different situation in our country: as a rule, students choose the simplest ways to solve the problems. According to some research studies, students tend to choose the easiest subjects (the most disappointing thing is that the study was conducted among medical students) [1].

We suggest the following practical recommendations that can provide real changes in legal education: the development of the clear set of training and methodological support for students, the proper planning of students' individual work, the development of methods of assessment which will show the real level of theoretical knowledge and ability to apply them in practice. During practical sessions not just the evaluation of retelling of the theoretical issues but open discussion based on equality and mutual respect of the participants should take place [10]. In addition, one should also take into account students' creativity, ability to deal with abnormal situations, etc. Besides, according to p. 23 of the Concept, it is necessary to increase the role of written works in teaching fundamental juridical disciplines and assessing students' knowledge. Writing control papers makes it possible to find out the level of students' knowledge within a short time, their ability to logically and consistently express their thoughts in a written form and, identify their opportunity to apply their knowledge in practice. The forms of written assessment involve tests, compositions, essays, reports, etc. Its advantage is fixation of the material that provides the ability to consider students' mistakes and find the ways to correct them.

Writing an essay is one of the most effective forms of written assessment of students' knowledge. It is an individual student's work on a proposed topic, in which he/she describes the issue in a free form and reasonably presents his/her opinion. This will promote the formation of such competencies (p. 17 concept) as the ability to think in abstract, logical, critical and creative ways, create new ideas, analyze the events; the ability to correctly and accurately formulate and express the opinion, properly substantiate it; skills to collect and analyze information that is extremely important for a lawyer.

3. Nekit, K. H. (2016). Problemy ta perspektyvy metodiv kontroliu navchalnykh dosiahnen studentiv yurydychnykh spetsialnostei [Problems and prospects of methods of academic achievements control of students of legal specialties]. Proceedings of International scientifically-educational internship "Innovative educational technologies: European Union experience and its implementation to the training of lawyers". (pp. 163-166). Bratislava, Slovak Republic: Pan-European university [in Ukrainian]. 
4. Konopatska, L. V. (2016). Rol systemy zvorotnoho zviazku (feedback) u pokrashchenni osvitnoho protsesu [Role of the feedback system in the improvement of the educational process]. Vseukrainska naukovo-metodychna konferentsiia za mizhnarodnoiu uchastiu "Studentotsentryzm $u$ systemi zabezpechennia yakosti osvity $v$ ekonomichnomu universyteti" - Proceedings of Ukrainian Scientific and Methodical Conference with international participation "Student-centered educational system in procuring of quality of education in economical university". (pp. 96-96). Kyiv: KNEU [in Ukrainian].

5. Tokar, V. V. (2016). Studentotsentryzm u systemi vnutrishnoho zabezpechennia yakosti osvity: implementatsiia v Ukraini dosvidu universytetiv SShA [Studentcentered educational system in interior system of procuring of quality of education: implementation of the USA experience in Ukraine]. Vseukrainska naukovometodychna konferentsiia za mizhnarodnoiu uchastiu "Studentotsentryzm u systemi zabezpechennia yakosti osvity $v$ ekonomichnomu universyteti" - Proceedings of Ukrainian Scientific and Methodical Conference with international participation "Student-centered educational system in procuring of quality of education in economical university”. (pp. 43-45). Kyiv: KNEU [in Ukrainian].

\section{ЛІТЕРАТУРА}

1. Зубченко Я. Болонська система по-українські: лінь та маніпуляція [Електронний ресурс] / Я. Зубченко. - 2016. - Режим доступу: http://osvita.ua/vnz/52421.

2. Носко И. В. Студентоцентрированное образование как основополагающий принцип болонских реформ в высшей школе / И. В. Носко // Вектор науки ТГУ. - 2011. - № 1(4). - С. 136-138.

3. Некіт К. Г. Проблеми та перспективи методів контролю навчальних досягнень студентів юридичних спеціальностей / К. Г. Некіт // Innovative educational technologies: European Union experience and its implementation to the training of lawyers: The abstracts of scientifically-methodological works by the results of international scientifically-educational internship (Bratislava, Slovak Republic, August, 10-13, 2016). Bratislava, Slovak Republic: Pan-European university, 2016. - C. 163-166.

4. Конопатська Л. В. Роль системи зворотнього зв'язку (feedback) у покращенні освітнього процесу / Л. В. Конопатська // Студентоцентризм у системі забезпечення якості освіти в економічному університеті : зб. матеріалів Всеукраїнської науковометодичної конференції за міжнародною участю, (Київ, 2-3 берез. 2016 р.). - Київ : КНЕУ, 2016. - С. 96-97.
6. Bologna with students' eyes. Structural reforms. Retrieved from: http://bwse2015.esuonline.org/Structrual+Reforms [in English]

7. Ofitsiinyi sait Ministerstva ekonomichnoho rozvytku $i$ torhivli Ukrainy [Official site of Ministry of Economic Development and Trade of Ukraine]. Retrieved from: http://me.gov.ua/Documents/List?lang=uk-

UA\&tag=UpravlinniaDerzhavnimSektoromEkonomikiIs\&s howArchive $=$ true \&showAllArchive=True [in Ukrainian].

8. Proekt Kontseptsii rozvytku vyshchoi yurydychnoi osvity v Ukraini (2009). [Draft Concept of development of high juridical education in Ukraine]. Yurydychnyi zhurnal. - Juridical journal, 11. Retrieved from: http://www.justinian.com.ua/article.php?id=3358 [in Ukrainian].

9. Bolonska systema [Bologna system]. Retrieved from: http://ksm.khnu.km.ua/bolonska-sistema [in Ukrainian].

10. Pidodvirna, Yu. (2014). Bolonska systema abo Bolonieze po-ukrainski [Bologna system or Bolognese in Ukrainian]. Retrieved from: http://studway.com.ua/bologna/.

5. Токар В. В. Студентоцентризм у системі внутрішнього забезпечення якості освіти: імплементація в Україні досвіду університетів США / В. В. Токар // Студентоцентризм у системі забезпечення якості освіти в економічному університеті : зб. матеріалів Всеукр. наук.-метод. конф. за міжнар. участю, (Київ, 2-3 берез. 2016 р.). - Київ : КНЕУ, 2016. - С. 43-45.

6. Bologna with students' eyes. Structural reforms [Електронний ресурс]. - 2015. - Режим доступу: http://bwse2015.esu-online.org/Structrual+Reforms.

7. Офіційний сайт Міністерства економічного розвитку і торгівлі України [Електронний ресурс] Режим http://me.gov.ua/Documents/List?lang=uk-

UA\&tag=UpravlinniaDerzhavnimSektoromEkonomikiIs $\&$ showArchive $=$ true $\&$ showAllArchive $=$ True .

8. Проект Концепції розвитку вищої юридичної освіти в Україні. - Юридичний журнал. - № 11. 2009. - [Електронний ресурс]. - Режим доступу: http://www.justinian.com.ua/article.php?id=3358.

9. Болонська система [Електронний ресурс] - Peжим доступу: http://ksm.khnu.km.ua/bolonska-sistema.

10. Підодвірна Ю. Болонська система або Болоньєзе по-українські [Електронний ресурс] / Юлія Підодвірна. - 2014. - Режим доступу: http://studway.com.ua/bologna/. 
Катерина Геораївна Некім, кандидат юридичних наук, доцент кафедри ичивільного права, Національний університет «Одеська юридична академія», вул. Фонтанська дорога, 25, Одеса, Украӥна

\section{СУЧАСНІ ПРОБЛЕМИ І ПЕРСПЕКТИВИ РЕФОРМИ ЮРИДИЧНОЇ ОСВІТИ В УКРАЇНІ}

У статті було проведено аналіз сучасного етапу реформування юридичної освіти, у результаті якого зроблено висновок про невідповідність задач, які вирішуються в ході реформ, поставленим в рамках Болонського процесу цілям. Зокрема, наголошується на нерозумінні сутності концепції студентоцентризму, наслідком чого $є$ iї неправильна реалізація. Зазначається, що студентоцентризм припускає активну участь студента в освітньому процесі, зокрема, у визначенні навчального контенту і процедури оцінювання. Проте, такий підхід орієнтований на свідомого студента з високою особистою мотивацією, яка викликана бажанням отримати якісну освіту, що, на жаль, сьогодні є характерним далеко не для кожного студента. Звернуто увагу на недоліки існуючої системи оцінювання результатів навчальних досягнень студентів. В Україні паралельно 3 кредитнотрансферною системою продовжує існувати національна система оцінювання, що створює проблеми при спробах їх порівняння. Особливу увагу в статті приділено аналізу проекту Концепції вдосконалення правової (юридичної) освіти для спеціалізованої підготовки правознавця відповідно до європейських стандартів вищої освіти і правової професії. Виявлено переваги й недоліки запропонованої Концепції. Зокрема, відмічено, що ііі плюсом $\epsilon$ введення єдиного кваліфікаційного іспиту для доступу до професії «Право». Позитивним слід вважати запропоноване Концепцією підвищення ролі письмових робіт при оцінюванні знань студентів юридичних спеціальностей. Недоліками є, зокрема, штучне обмеження числа студентів юридичних спеціальностей, введення наскрізної магістратури, що суперечить принципам Болонської конвенції. За результатами проведеного аналізу висунуто пропозиції щодо вдосконалення реформ, що проводяться у сфері юридичної освіти, зокрема, наголошено на необхідності підвищення особистої відповідальності студентів, розробки чітких навчально-методичних комплексів, належного планування самостійної роботи студентів, розробки адекватних методів контролю, підвищення ролі есе для формування професійних компетентностей студентів юридичних спеціальностей. Написання есе дозволяє студенту навчитися структуровано й послідовно формулювати і висловлювати власні думки, виявляти причинно-наслідкові зв'язки, творчо, але обгрунтовано підходити до вирішення проблем тощо. Вказані навички необхідні в рамках формування таких компетентностей юриста, як здібність до абстрактного, логічного, критичного та творчого мислення, генерації нових ідей тощо.

Ключові слова: юридична освіта, реформування, Концепція вдосконалення правової освіти, студентоцентризм, оцінювання.

Reviewed by Doctor of Law, prof. N. Holubieva

Submitted on February, 22, 2017 